\title{
Faktor - Faktor Yang Mempengaruhi Kemampuan Laba Pada Shipyard PT. Dok Dan Perkapalan Kodja Bahari (Persero) Periode 2013 - 2017
}

\author{
Dewi Cahyani Pangestuti
}

Fakultas Ekonomi dan Bisnis Universitas Pembangunan Nasional "Veteran” Jakarta

\begin{abstract}
The purpose of this study is to analyze the influence of liquidity, debt level and efficiency of working capital together to profit ability at PT Dok dan Perkapalan Kodja Bahari (Persero). The method of research conducted is a method of quantitative data analysis. The number of samples researched were 50 financial report data of Shipyard PT Dok dan Perkapalan Kodja Bahari (Persero) from 2013 until 2017.

The conclusions of this study are as follows: partially current ratio, debt to asset ratio, working capital turnover (CR, DTAR, WCT) have significant effect on EBITDA Margin. Of the three variables that proved significant, Working Capital Turnover(WCT) is the dominant variable that affects EBITDA Margin, followed by variable debt to asset ratio (DTAR) and last variable current ratio (CR). Simultaneously current ratio, debt to asset ratio, working capital turnover (CR, DTAR, $W C T)$ proved to have a significant effect on EBITDA Margin.
\end{abstract}

Keywords : current ratio, debt to asset ratio, working capital turnover, EBITDA Margin Correspondence to : dewichepe@yahoo.com

\begin{abstract}
ABSTRAK
Tujuan dari penelitian ini adalah menganalisis pengaruh likuiditas, tingkat utang dan efisiensi modal kerja terhadap kemampuan laba pada PT Dok dan Perkapalan Kodja Bahari (Persero). Metode penelitian mengunakan analisa data kuantitatif. Jumlah sampel yang diteliti sebanyak 50 data laporan keuangan sejak tahun 2013 -2017.

Kesimpulan penelitian ini adalah: secara parsial variabel Likuiditas, Tingkat Utang serta Efisiensi Modal Kerja (CR, DTAR, WCT) terbukti berpengaruh signifikan terhadap EBITDA Margin. Dari tiga variabel yang terbukti signifikan, Efisiensi Modal Kerja (WCT) merupakan variabel dominan yang berpengaruh terhadap EBITDA Margin, disusul variabel tingkat utang (DTAR) dan terakhir variabel likuiditas (CR). Secara simultan likuiditas, tingkat utang serta efisiensi modal kerja (CR, DTAR, WCT) terbukti berpengaruh signifikan terhadap EBITDA Margin.
\end{abstract}

Kata kunci : Likuiditas, Tingkat Utang, Efisiensi Modal Kerja, Kemampuan Laba

Korespondensi : : dewichepe@yahoo.com

\section{PENDAHULUAN / INTRODUCTION}

PT Dok \& Perkapalan Kodja Bahari

(Persero) merupakan galangan kapal yang bergerak dalam bidang usaha pembangunan kapal baru dan pemeliharaan \& perbaikan kapal secara umum tujuan utamanya adalah memperoleh laba sesuai dengan yang ditargetkan dalam RUPS. Selama 5 tahun terakhir target laba bersih berfluktuatif bahkan 2 tahun terakhir mengalami kerugian. Laporan 
Laba dan Rugi Komprehensif dalam kurun waktu 5 (lima) tahun terakhir terlihat bahwa tahun 2017 mengalami kerugian sebesar Rp. 175,9 milyar, tahun 2016 mengalami kerugian sebesar sebesar Rp. 2.5 milyar, tahun 2015 membukukan laba sebesar Rp. 9.9 milyar, tahun 2014 membukukan laba Rp.43.3 milyar, dan 2013 membukukan laba Rp. 72.8 juta. Kondisi keuangan perusahan tersebut diperburuk lagi dengan adanya kewajiban yang jatuh tempo tidak dapat diselesaikan oleh perusahaan, total hutang lebih besar dari total aset dan ekuitas negatif.

Rencana Kerja dan Anggaran yang disusun oleh perusahaan yang berisikan targettarget perusahaan kemudian ditetapkan dalam RUPS, diturunkan menjadi target tiap-tiap sub unit usaha. Tiap-tiap sub unit usaha di internal PT Dok \& Perkapalan Kodja Bahari (Persero) disebut Shipyard. PT Dok \& Perkapalan Kodja Bahari (Persero) mempunyai 10 (sepuluh) Shipyard yang berlokasi 3 (tiga) Jakarta dan 7 diluar Jakarta yang terletak di Cirebon, Semarang, Palembang, Padang, Banjarmasin dan Batam. Masing-masing Shipyard di pimpin oleh seorang General Manajer. Sehingga Shipyard merupakan Profit Center yaitu pusat pertanggungan jawab untuk peroleh laba operasional diluar penyusutan dan amortisasi (earning before interest, tax, depreciation and amortization disingkat EBITDA). Sedangkan beban penyusutan dan amortisasi merupakan beban Kantor Pusat sebagai Investment and Financing Center yang dalam struktur organisasi yaitu terdiri atas Dewan Direksi dan Komisaris.

Dalam 5 (lima) tahun terakhir sejak tahun 2013 sampai dengan 2017 hampir seluruh Shipyard target EBITDA tidak tercapai sehingga berdampak pada target korporasi, dengan kata lain EBITDA dari seluruh cabang tidak mampu menopang beban Kantor Pusat sebagai Invesment and Financing Center. Kemampuan laba atau profitabilitas tidak terlepas dari faktor likuiditas, tingkat utang dan efisiensi modal kerja. Likuiditas yaitu salah satu faktor yang sangat penting, karena tingkat likuiditas mencerminkan kemampuan perusahaan dalam membayar kewajiban jangka pendek yang jatuh tempo (Rahmawati, 2015). Untuk memenuhi kewajiban tersebut, manajeman harus mempersiapkan aset yang benar-benar siap menjadi uang kas dalam waktu dan jumlah yang sesuai. Oleh karena itu pengukuran atas kemampuan membayar kewajiban jangka pendek harus hati-hati mulai dari yang pesimistik sampai dengan optimistik dilihat dari jumlah dan waktu tersedianya dana yang dibutuhkan untuk membayar kewajiban jangka pendek. Dalam pengukuran likuiditas diperlukan norma-norma untuk mengukur keadaan tingkat likuiditas. Dalam kenyataannya pengendalian keuangan tidak jarang menimbulkan masalah seperti likuiditas berlebihan (over liquid) dan likuiditas rendah (under liquid). Kebijakan pengelolaan likuiditas setiap perusahaan berbeda-beda, 
dalam menghadapi kondisi likuiditas berlebihan (over liquid) maupun likuiditas rendah (under liquid). Manajer Keuangan akan menghadapi keadaaan dimana ada pertukaran (trade-off) antara likuiditas dan kemampuan laba. Keputusan untuk menekan likuiditas agar tetap terjaga, kemungkinan dapat mempenguhi kemampuan laba perusahaan, Namun sebaliknya keputusan yang memaksimalkan laba perusahaan, kemungkinan dapat mempengaruhi tingkat likuiditas. Sehingga dapat disampaikan bahwa likuiditas berpengaruh terhadap kemampuan laba.

Disamping keputusan diatas, pihak manajemen Shipyard PT Dok \& Perkapalan Kodja Bahari (Persero) juga dihadapkan dibidang keuangan lainnya yaitu sumber dana untuk mendukung operasional perusahaan. Dalam dunia bisnis hampir tidak ada lagi perusahaan yang mengguankan modal sendiri, tetapi merupakan sesuatu yang biasa didukung dari utang. Pengadaan bahan baku secara kredit akan menimbulkan hutang, penangguhan pembayaran pajak, sewa dan lain-lain yang disebut beban akrual. Keputusan perusahaan atas pembiayaan tersebut berakibat adanya kewajiban untuk membayar/melunasi biaya tetap seperti cicilan pokok dan beban bunga tetapi dengan utang tersebut kegiatan operasional perusahaan dapat berjalan lancar dan dapat penjualan sehingga dapat mempengaruhi kemampuan laba. Tingkat utang atau rasio utang merupakan ukuran seberapa besar operasional perusahaan dibiayai dari unsur utang, dan seberapa besar kemampuan perusahaan dari hasil operasinya untuk melunasi beban tetap berupa cicilan pokok dan bunga, sehingga tingkat utang akan mempengaruhi kemampuan laba.

Modal kerja merupakan aspek penting dalam perusahaan karena menjadi faktor penentu berjalannya kegiatan operasional perusahaan yang secara langsung berpengaruh terhadap pendapatan perusahaan (Dewi dan Prasetiono, 2011). Sumber modal kerja Shipyard PT Dok \& Perkapalan Kodja Bahari (Persero) selain dari Kantor Pusat berasal dari kredit supplier dan berupa bahan baku yang disuplai dari pemilik kapal. Kredit supplier terjadi karena terbatasnya modal kerja Shipyard dan diakibatkan oleh valume pekerjaan diatas rata-rata. Sedangkan bahan baku dari pemilik kapal (supply owner) karena terdapat equipment kapal tertentu yang tidak tersedia di gudang Shipyard maupun dipasaran dalam negeri maupun luar negeri. Untuk mengadakan equipment kapal tersebut diperlukan waktu beberapa bulan untuk proses pengadanaan dan atau proses pembuatannya.

Dalam penelitian terdahulu terdapat perbedaan (gap) terhadap hasil-hasil penelitian sebagai berikut : Likuiditas menurut Awan (2014), bahwa likuditas berpengaruh negatif dan signifikan terhadap profitabilitas sedangkan menurut Wibowo dan Wartini (2012), bahwa tidak ada pengaruh 
likuiditas terhadap profitabilitas. Financial leverage mempunyai pengaruh signifikan dan negatif terhadap profitabilitas (Taani (2012), tetapi menurut Wibowo dan Wartini (2012), bahwa tidak ada pengaruh leverage terhadap profitabilitas. Menurut Wibowo dan Wartini (2012) bahwa efesiensi modal kerja berpengaruh positif dan signifikan terhadap profitabilitas, tetapi menurut Kumara dan Saputra (2104), bahwa efisiensi modal kerja berpengaruh signifikan dan negatif terhadap profitabilitas,

Selain terjadi perbedaan (gap) terhadap hasil-hasil penelitian terdahulu, terjadi juga gap antara teori dengan hasil penelitian sebagai berikut : Adanya hubungan negatif (trade-off) antara tingkat likuiditas dengan profitabilitas (Sitanggang 2014). Apabila kebijakan untuk mempertahankan tingkat likuiditas yang tinggi maka dengan sendirinya akan berdampak pada profitabilitas yang rendah serta sebaliknya pada tingkat likuiditas yang rendah akan berdampak pada profitabilitas yang tinggi. Sedangkan menurut hasil penelitian Wibowo dan Wartini (2012), bahwa tidak ada pengaruh likuiditas terhadap profitabilitas.

Berdasarkan gambaran permasalahan diatas, adanya gap hasil-hasil penelitian terdahulu dan adanya gap antara teori dan hasil penelitian maka penulis tertarik untuk menganalisis pengaruh likuiditas, tingkat utang dan efisiensi modal kerja terhadap kemampuan laba pada Shipyard PT Dok \&
Perkapalan Kodja Bahari (Persero) Periode 2013 - 2017.

\section{PERUMUSAN HIPOTESIS}

a. Pengaruh likuiditas terhadap

\section{kemampuan laba}

Menurut Stephen dkk (2012, p.22) liquidity refers to the speed and ease with which an assets can be converted to cash. Likuiditas merupakan mengacu pada kecepatan dan kemudahan aset perusahaan menjadi kas. Biasanya dalam perusahaan ada target tertentu berapa lama aset tersebut menjadi kas. Contohnya berapa persediaan dijual kemudian menjadi piutang dan piutang ditagih menjadi cash.

Hubungan negatif (trade-off) antara likuiditas dengan profitabilitas. Apabila kebijakan untuk mempertahankan tingkat likuiditas yang tinggi maka dengan sendirinya akan berdampak pada tingkat profitabilitas yang rendah dan sebaliknya pada tingkat likuiditas yang rendah akan berdampak pada profitabilitas yang tinggi. (Sitanggang 2014, hlm. 77)

Dalam penelitian Awan (2014, p. 110), bahwa rasio lancar mempunyai hubungan signifikan dan negatif dengan return on asset, Jika rasio lancar meningkat maka return on asset menurun. Maka berlandaskan pada teori dan penelitian yang pernah dilakukan, dapat dibangun suatu hipotesis bahwa likuiditas berpengaruh terhadap kemampuan laba. 


\section{b. Pengaruh tingkat utang terhadap kemampuan laba}

Brealey dkk (2007, p. 744) menyatakan Leverage ratios measure how much financial leverage the firm has take on. Utang meningkatan pengembalian bagi pemegang saham dalam masa-masa baik dan mengurangi pengembalian dimasa-masa sulit, sehingga utang menciptakan leverage keuangan. Rasio leverage mengukur seberapa besar leverage keuangan ditanggung oleh perusahaan. Sitanggang (2014, hlm. 23) menyatakan bahwa rasio utang (leverage) merupakan ukuran seberapa besar perusahaan dibiayai dari unsur utang dan seberapa besar kemampuan perusahaan untuk melunasi beban bunga dan atau pokok pinjaman tersebut. Dengan demikian tingkat utang merupakan ukuran seberapa besar porsi pembiayaan perusahaan dari sumber utang dan seberapa besar kemampuan dari hasil kegiatan perusahaan untuk dapat melunasinya.

Penelitian oleh Taani (2012, p.1) yang menyimpulkan bahwa, financial leverage menunjukkan hubungan negatif terhadap kinerja keuangan perusahaan yang dari segi laba bersih (net income), return on equity (ROE) dan return on asset (ROA) pada perusahaan industri di Bursa Efek Aman Yordania. Dari teori dan penelitian yang pernah dilakukan, dapat dibangun suatu hipotesis bahwa tingkat utang berpengaruh terhadap kemampuan laba.

\section{c. Pengaruh efisiensi modal kerja terhadap kemampuan laba}

Pengertian modal kerja atau working capital menurut Harjito dan Martono (2010, hlm. 74), mengatakan bahwa 'Dana yang dipergunakan untuk mendanai kegiatan perusahaan sehari-hari disebut modal kerja'. Modal kerja menurut Sutrisno (2013, hlm. 41), seperti pembelian bahan baku, pembayaran upah buruh, membayar hutang, dan pembayaran lainnya.

Perputaran modal kerja atau working capital turnover yang diukur dengan penjualan dibagi dengan aktiva lancar, menunjukkan lamanya uang kas untuk membeli bahan, membayar upah untuk menjadi barang jadi dan siap dijual dan ditagih hingga kembali kas (Sitanggang 1014, hlm. 61).

Penelitian oleh Kumara dan Saputra (2014, hlm. 352), menunjukkan bahwa perputaran modal kerja memiliki pengaruh negatif signifikan terhadap profitabilitas Koperasi Serba Usaha di Kecamatan Penebel Tahun 2010-2012. Demikian juga hasil penelitian Taani (2012, p. 14), menunjukkan hasil bahwa kebijakan manajemen modal kerja menunjukkan hubungan positif terhadap laba bersih perusahaan pada perusahaan industri yang terdaftar di bursa efek Aman Yordania. Maka berdasarkan teori yang ada dan penelitian yang pernah dilakukan, dapat dibangun suatu hipotesis bahwa efisiensi modal kerja berpengaruh terhadap 
kemampuan laba.

\section{d. Pengaruh Likuiditas, Tingkat Utang} dan Efisiensi Modal Kerja Terhadap Kemampuan Laba.

Manajemen likuiditas, tingkat utang dan efisiensi modal kerja merupakan salah satu aspek yang harus diperhatikan dalam perusahaan. Dengan manajemen yang baik terhadap likuiditas, tingkat utang dan efisiensi modal kerja diharapkan dapat mencapai laba yang maksimal atau sesuai yang diharapkan oleh pemegang saham.

Hasil penelitian Wibowo dan Wartini (2011, hlm. 57) bahwa variabel efisiensi modal kerja, likuiditas dan leverage bersamasama berpengaruh signifikan terhadap profitabilitas perusahaan. Demikian juga peneltian oleh Awan (2014, p. 111) menghasilkan kesimpulan bahwa secara bersama-sama varibabel likuiditas, leverage dan inflasi memiliki pengaruh positif dan signifikan terhadap profitabilitas perusahaan pada perusahaan yang bergerak di sektor makanan di Pakistan.

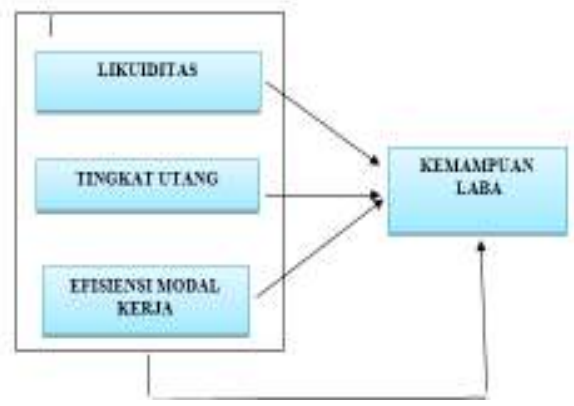

Gambar 1 . Model Penelitian

\section{METODE PENELITIAN / METHODS}

Penelitian ini menggunakan data panel karena menggunakan data panel memiliki beberapa keuntungan utama dibandingkan data jenis cross section maupun time series.

\section{Uji Asumsi Klasik}

Uji asumsi klasik meliputi :

\section{Uji Normalitas Data}

Uji normalitas data bertujuan untuk melihat apakah sampel-sampel yang diambil mempunyai seabran data yang normal atau tidak.

\section{Uji Multikolinearitas}

Untuk mengetahui korelasi dinatara beberapa atau semua variabel bebas.

\section{Uji Heterokedasitas}

Heteroskedasitas adalah menguji apakah variabel gangguan (disturbance/ error terms) yang muncul dalam fungsi regresi memiliki varians yang sama atau tidak.

\section{Uji Autokorelasi}

Autokorelasi merupakan korelasi yang terjadi pada error antar serial waktu (time series), sehingga diperlukan uji autokorelasi ini untuk memastikan model yang dibangun adalah baik dan representatif.

\section{Koefisien Determinasi}

Uji regresi ditujukan untuk mengetahui pengaruh setiap variabel bebas terhadap variabel terikat baik secara simultan maupun parsial. Koefisien determinasi $\mathrm{R}^{2}$ adalah bilangan yang menyatakan prosentasi variasi total $\mathrm{Y}$ yang dijelaskan oleh garis regresi. Koefisien determinasi ini dapat diperoleh dari 
rasio/perbandingan $\mathrm{Y}^{\prime}$ dengan varians $\mathrm{Y}$. Selanjutnya dilakukan Uji - uji sebagai berikut; Koefisien determinasi $\mathrm{R}^{2}$, analisa Varian F dan uji statitik - $\mathrm{t}$

\section{PEMBAHASAN / DISCUSSION}

Secara umum regresi data panel memiliki empat bentuk meliputi Model OLS Pooled, Model Fixed Effect Least Square Dummy Variabel (LVSD), Model Fixed Effect Within-Group, dan Model Random Effect. Pemilihan model (common, fixed atau random) dilakukan dengan melakukan analisis secara bertahap. Adapun tahapan ujinya adalah :

\section{a. Uji Chow (Pooled Least square Vs}

\section{Fixed Effect)}

Seperti kita ketahui bahwa metode Commont Constant (Pooled Least Square) terlalu sederhana untuk mendiskripsikan fenomena yang ada, maka perlu dilakukan untuk menemukan nature yang spesifik atas hubungan yang terjadi antara masing-masing individu pada data cross-section. Dengan software Eview 7.1 dapat kita melakukan uji Chow untuk menentukan apakah model yang terbaik untuk digunakan menggunakan commont constant atau Fixed effect model dengan hipotesis sebagai berikut :

$\mathrm{H}_{\mathrm{o}}$ : Pooled Least square (commont) effect

$\mathrm{H}_{1}$ : Fixed effect Model

Jika p-value $0.000<0.05$, maka metode Fixed effect lebih baik untuk mengestimasi data panel.

\section{Tabel 1. Chow Test}

\begin{tabular}{|c|c|c|c|}
\hline \multicolumn{4}{|c|}{$\begin{array}{l}\text { Redundant Fixed Effects Tests } \\
\text { Equation: FEM } \\
\text { Test cross-section fixed effects }\end{array}$} \\
\hline Effects Test & Statistic & d.f. & Prob. \\
\hline Cross-section $\mathrm{F}$ & 3.226964 & $(9,36)$ & 0.0030 \\
\hline Cross-section Chi-square & 23.109273 & 9 & 0.0015 \\
\hline
\end{tabular}

Dari hasil Redundant fixed effect didapatkan hasil p-value $0.0030<0,05$, sehingga $\mathrm{H}_{0}$ ditolak dan $\mathrm{H}_{\mathrm{I}}$ diterima, artinya model mengikuti fixed effect, karena model fixed effect lebih baik daripada Pooled Least Square (Common Effect).

\section{b. Uji Hausman}

Uji Hausman dilakukan untuk menetapkan model yang digunakan apakah Efek Tetap (Fixed Effect) atau Efek Random (Random Effect). Hipotesis yang diajukan adalah :

$\mathrm{H}_{0}$ : Model mengikuti REM

$\mathrm{H}_{1}$ : Model mengikuti FEM

Tabel 2. Hausman Test

\begin{tabular}{|c|c|c|c|}
\hline \multicolumn{4}{|c|}{$\begin{array}{l}\text { Correlated Random Effects - Hausman Test } \\
\text { Equation: REM } \\
\text { Test cross-section random effects }\end{array}$} \\
\hline Test Summary & Chi-Sq. Statistic & Chi-Sq. d.f. & Prob \\
\hline Cross-section random & 0.971237 & 3 & 0.808 \\
\hline \multicolumn{4}{|c|}{ Sumber c data lapangan, diolah dengan EVIEWS 7.1} \\
\hline Probabilitas & uji & $\mathrm{Hau}$ & nan \\
\hline
\end{tabular}

menunjukkan nilai chi-square tidak signifikan secara statistic, karena $0,8082>0,05$, maka $\mathrm{H}_{1}$ ditolak dan $\mathrm{H}_{0}$ diterima, sehingga dapat disimpulkan model mengikuti random effect karena akan lebih baik daripada mengikuti fixed effect. 


\section{c. Analisis Regresi Data Panel}

Metode Random Effect (REM) merupakan salah satu metode dari regresi data panel. Dan lebih dikenal dengan Error Component Model. Adapun hasil dari metode Random Effect adalah:

Tabel 3. Metode Random Effect

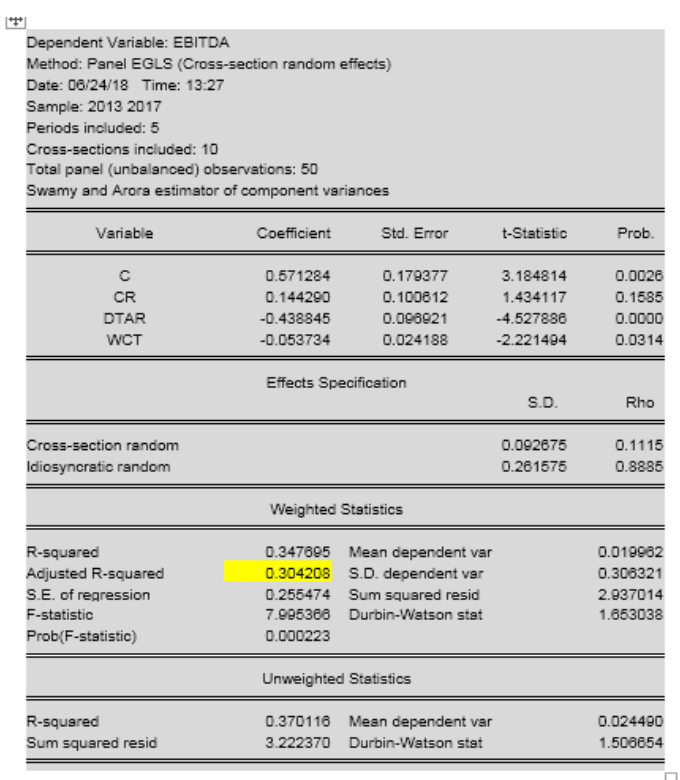

Hasil estimasi pada model Random Effect menghasilkan besaran koefisien pengaruh simultan (adjusted R-Squared) sebesar $0,304208(30,42 \%)$ dan sisanya sebesar $69,58 \%$ dipengaruhi oleh variabel lain, dengan probabilitas F sebesar $0,000223<0,05$. Hasil uji ini menunjukkan hasil bahwa secara simultan variabel likuiditas, tingkat utang dan Efisiensi Modal Kerja (CR, DTAR, WCT) secra simultan berpengaruh terhadap Kemampuan Laba (EBITDA Margin).

Dengan menggunakan prinsip kesederhanaan (parsimony) dan memandang nilai kuadrat error (sum of squared residual) minimal, dapat ditarik kesimpulan bahwa model terbaik adalah model Random Effect (REM) dengan efek individu / cross section. Dengan demikian, model regresi membolehkan perbedaan untuk masingmasing individu atau cross section memiliki karakteristik khusus :

Tabel 4. Intercept Per Individu

\begin{tabular}{|c|l|c|}
\hline No & \multicolumn{1}{|c|}{ Keterangan } & Effect \\
\hline 1 & Shipyard I Jakarta & 0.096116 \\
\hline 2 & Shipyard II Jakarta & -0.245044 \\
\hline 3 & Shipyard III Jakarta & 0.041552 \\
\hline 4 & Shipyard Cirebon & 0.119639 \\
\hline 5 & Shipyard Semarang & 0.180159 \\
\hline 6 & Shipyard Palembang & -0.142829 \\
\hline 7 & Shipyard Padang & -0.127696 \\
\hline 8 & Shipyard Sabang & -0.024923 \\
\hline 9 & Shipyard Banjarmasin & 0.101801 \\
\hline 10 & Shipyard Batam & 0.001530 \\
\hline
\end{tabular}

Persamaan regresi dari model penelitian secara keseluruhan diuraikan seperti pada tabel 5 :

Tabel 5. Persamaan Regresi

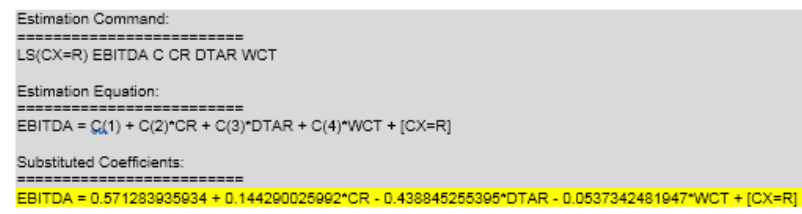

EBITDA Margin $=0.571284+0.144290 * C R-$

\section{$0.438845 *$ DTAR- $0.053734 *$ WCT}

Interprestasi dari persamaan di atas adalah :

Nilai pada persamaan di atas, adalah :

1). Nilai konstanta (intercept) model simultan adalah sebesar 0.571284. Dapat dikatakan jika Likuiditas, Tingkat Utang dan Efisiensi Modal Kerja (CR, DTAR, WCT) bernilai konstan, maka besaran nilai Kemampuan Laba (EBITDA Margin) adalah 0.571284 .

2). Koefisien regresi Likuiditas (CR) adalah sebesar 0.144290 . artinya setiap kenaikan $1 \%$ 
pada CR akan meningkatkan EBITDA Margin sebesar 0.144290.

3). Koefisien regresi Tingkat Utang (DTAR) adalah sebesar -0.438845, artinya setiap kenaikan $1 \%$ pada DTAR akan menurunkan EBITDA Margin sebesar 0.438845 satuan.

4). Koefisien regresi Efisiensi Modal Kerja (WCT) adalah sebesar -0.053734, artinya setiap kenaikan $1 \%$ pada WCT akan menurunkan EBITDA Margin sebesar 0.053734 satuan.

\section{e. Pengujian Pengaruh Parsial}

Setelah berhasil diidentifikasi bahwa model yang dipilih adalah random effect berdasarkan uji Hausman, maka selanjutnya model yang digunakan untuk menjawab hipotesis yang diajukan adalah metode random effect. Hasil pengujian hipotesis selanjutnya diuraikan seperti tabel 6 :

\section{Tabel 6. Pengujian Model Parsial}

\begin{tabular}{crrrr} 
Variable & Coeficient & Std. Error & t-Statistic & Prob. \\
\hline \hline C & 0.571284 & 0.179377 & 3.184814 & 0.002 \\
CR & 0.144290 & 0.100812 & 1.434117 & 0.158 \\
DTAR & -0.438845 & 0.096921 & -4.527886 & 0.000 \\
WCT & -0.053734 & 0.024188 & -2.221494 & 0.011 \\
\hline \hline
\end{tabular}

Sumber: data diolah, Eviews 7.1.

1). Pengaruh parsial likuiditas (CR) terhadap Kemampuan Laba (EBITDA Margin).

Berdasarkan hasil analisis diketahui bahwa likuiditas (CR) tidak berpengaruh signifikan terhadap Kemampuan Laba (EBITDA Margin). Hal ini dapat dilihat dari nilai probabilitas 0.1585 (>0.025). Hasil uji probabilitas ini juga relevan dengan membandingkan nilai $\mathrm{t}$ hitung $(\mathrm{t}$ hitung $=$ $\left.0,1434117<t_{\text {tabel }}=2,01063\right)$. Sehingga dapat dinyatakan bahwa $\mathrm{H}_{0}$ diterima, artinya likuiditas (CR) secara signifikan tidak berpengaruh signifikan terhadap Kemampuan Laba (EBITDA Margin) berdasarkan data yang diobservasi.

2). Pengaruh parsial tingkat utang (DTAR) terhadap Kemampuan Laba (EBITDA Margin)

Berdasarkan hasil analisis diketahui bahwa tingkat utang (DTAR) terbukti berpengaruh negatif dan signifikan terhadap Kemampuan Laba (EBITDA Margin). Hal ini dapat dilihat dari nilai probabilitas $0.0000(<$ 0.025). Hasil uji probabilitas ini juga relevan dengan membandingkan nilai $\mathrm{t}_{\text {hitung }}\left(\mathrm{t}_{\text {hitung }}=\right.$ $\left.4,527886<\mathrm{t}_{\text {tabel }}=-2,01063\right)$. Sehingga dapat dinyatakan bahwa $\mathrm{H}_{0}$ ditolak, artinya secara signifikan tingkat utang (DTAR) berpengaruh signifikan terhadap Kemampuan Laba (EBITDA Margin)

3). Pengaruh parsial Efisiensi Modal Kerja (WCT) terhadap Kemampuan Laba (EBITDA Margin)

Berdasarkan hasil analisis diketahui bahwa Efisiensi Modal Kerja (WCT) terbukti berpengaruh negatif dan signifikan terhadap Kemampuan Laba (EBITDA Margin). Hal ini dapat dilihat dari nilai probabilitas 0.0114 (< 0.025). Hasil uji probabilitas ini juga relevan dengan membandingkan nilai $\mathrm{t}_{\text {hitung }}\left(\mathrm{t}_{\text {hitung }}=\right.$ $\left.2.221494<t_{\text {tabel }}=-2,01063\right)$. Sehingga dapat dinyatakan bahwa $\mathrm{H}_{0}$ diterima, artinya Efisiensi Modal Kerja (WCT) berpengaruh 
negatif dan signifikan terhadap Kemampuan

Laba (EBITDA Margin).

\section{f. Pengujian Pengaruh Simultan}

Pengaruh simultan Likuiditas, Tingkat Utang dan Efisiensi Modal Kerja (CR, DTAR, WCT) terhadap Kemampuan Laba (EBITDA Margin). Pengujian hipotesis secara simultan dapat dilihat pada tabel di bawah ini :

\section{Tabel 7. Pengujian Model Simultan}

\begin{tabular}{|c|c|c|c|c|}
\hline \multicolumn{5}{|c|}{ Effects Specification } \\
\hline & & & S.D. & Rho \\
\hline $\begin{array}{l}\text { Cross-section random } \\
\text { Idiosyncratic random }\end{array}$ & & & $\begin{array}{l}0.082875 \\
0.281575\end{array}$ & $\begin{array}{l}0.1115 \\
0.8885\end{array}$ \\
\hline \multicolumn{5}{|c|}{ Weighted Statistics } \\
\hline R-squared & 0.347685 & Mean dependent var & & 0.018982 \\
\hline Adjusted R-squared & 0.304208 & S.D. dependent var & & 0.308321 \\
\hline S.E. of regression & 0.255474 & Sum squared resid & & 2.837014 \\
\hline F-statistic & 7.895368 & Durbin-Watson stat & & 1.853038 \\
\hline Prob(F-stgtistic) & 0.000223 & & & \\
\hline
\end{tabular}

Dengan menggunakan perhitungan

Eviews 7.1 dalam uji hipotesis adalah sebagai berikut :

- $\quad$ Jika $\mathrm{F}_{\text {hitung }}<\mathrm{F}_{\text {tabel, }}$ maka $\mathrm{H}_{0}$ diterima dan $\mathrm{H}_{\mathrm{a}}$ ditolak

- $\quad$ Jika $\mathrm{F}_{\text {hitung }}>\mathrm{F}_{\text {tabel, }}$ maka $\mathrm{H}_{0}$ ditolak dan $\mathrm{H}_{\mathrm{a}}$ diterima

Dari tabel diperoleh nilai Prob (F statistic) atau nilai Sig. sebesar $0.000223<$ 0.05 , atau besarnya $\mathrm{F}_{\text {hitung }}=7.995366>\mathrm{F}_{\text {tabel }}$ $=2,81$, hal ini berarti bahwa $\mathrm{H}_{0}$ ditolak, maka dapat disimpulkan bahwa variabel Likuiditas, Tingkat Utang dan Efisiensi Modal Kerja (CR, DTAR, WCT) berpengaruh secara simultan terhadap Kemampuan Laba (EBITDA Margin).

Hasil estimasi dengan metode Random Effect menghasilkan koefisien pengaruh simultan (adjusted R-Squared) sebesar 0.304208 artinya variasi EBITDA Margin dapat dijelaskan oleh ke 3 variabel bebas (CR, DTAR dan WCT) sebesar 30,4208\% dan sisanya sebesar 69,5792\% dipengaruhi oleh variabel lain diluar penelitian ini. Probabilitas F sebesar 0.000, kurang dari 0.05 ini membuktikan bahwa variabilitas variabel dependen paling tidak dipengaruhi oleh salah satu dari variabel independen yaitu CR, DTAR, WCT likuiditas, tingkat utang dan Efisiensi Modal Kerja secara simultan berpengaruh terhadap Kemampuan Laba (EBITDA Margin) sebesar 30,4208\%.

\section{KESIMPULAN / CONCLUSSION}

Kesimpulan yang dapat diambil dalam penelitian ini adalah :

a. Secara parsial variabel Tingkat Utang dan Efisiensi Modal Kerja (DTAR dan WCT) terbukti berpengaruh signifikan terhadap EBITDA Margin. Sedangkan likuiditas (CR) tidak berpengaruh signifikan terhadap EBITDA Margin. Variabel tingkat utang (DTAR) merupakan variabel dominan yang berpengaruh terhadap EBITDA Margin, disusul dengan variabel Efisiensi Modal Kerja (WCT) dan terakhir variabel likuiditas (CR).

b. Secara simultan likuiditas, tingkat utang dan Efisiensi Modal Kerja (CR, DTAR, WCT) terbukti berpengaruh signifikan terhadap EBITDA Margin.

c. Koefisien determinasi model simultan menghasilkan nilai adjusted R-Squared) sebesar 0.304208 artinya variasi EBITDA 
Margin dapat dijelaskan oleh ke 3 variabel bebas (CR, DTAR dan WCT) sebesar $30,4208 \%$ dan sisanya sebesar $69,5792 \%$ dipengaruhi oleh variabel lain diluar penelitian ini. Hal ini membuktikan bahwa variabilitas variabel dependen, paling tidak dipengaruhi oleh salah satu dari variabel independen yaitu CR, DTAR, WCT atau dengan kata lain, secara simultan variabel likuiditas, tingkat utang dan Efisiensi Modal Kerja (CR, DTAR, WCT) berpengaruh terhadap Kemampuan Laba (EBITDA Margin) sebesar 30,4208\%.

d. Persamaan regresi yang diperoleh adalah EBITDA Margin $=0.571284+$ $0.144290 *$ CR-0.0.438845*DTAR$0.053734 * \mathrm{WCT}$.

\section{KETERBATASAN DAN SARAN}

Kepada para peneliti lainnya disarankan untuk meneliti variabel lain - lain yang masih mempengaruhi kemampuan laba dengan bermacam metode penelitian yang sesuai. Untuk peneitian lanjutan perlu menggunakan data dan sampel yang lebih luas. Ini dimaksudkan agar kesimpulan yang dihasilkan dari penelitian tersebut memiliki cakupan yang lebih luas dan tidak hanya dari satu jenis industri saja karena penentuan jumlah kerja bagi suatu perusahaan juga dipengaruhi oleh sifat atau tipe perusahaan.

\section{DAFTAR PUSTAKA / BIBLIOGRAPHY}

Agus Harjito dan Martono, (2011), Manajemen Keuangan, Edisi kedua, Cetakan Kedua, Ekonisia, Yogyakarta.

Agus Wibowo dan Sri Wartini, (2012), Efisiensi Modal Kerja, Likuiditas, dan Leverage Terhadap Profitabilitas pada Perusahaan Manufaktur di $B E I$, Universitas Negeri Semarang.

Dewa Putu Kumara dan I Gde Dharma Saputra, (2014), Pengaruh Efisiensi Modal Kerja pada Profitabilitas Koperasi Serba Usaha, Universitas Udayana.

Dewi, D. R., \& prasetiono, P. (2011). Faktor-faktor yang mempengaruhi profitabilitas bank syariah di Indonesia (Doctoral dissertation, Universitas Diponegoro).

Khalaf Taani, (2012), Impact Working Capital Management Policy and Financial Leverage on Financial Perfomance: Impirical Evidence from Amman Stock Exchange-listened Companies, International Journal of Management Sciences and Business Research, Vol. 1, Issue 8. (ISSN: 2226 -8235)

Maria Rasheed Awan, (2014), Impact of Liquidity, Leverage, Inflation on Firm Profitability an empirical analysis of food sector of Pakistan, IOSR Juonal of Business and Mangement, Volume 16, e-ISSN: 2278-487X, p-ISSN: 2319 7668

Rachmawati, A. A. (2015). Pengaruh Rasio Keuangan dan Kebijakan Dividen Terhadap Pertumbuhan Laba Pada Perusahaan Manufaktur yang Terdaftar di BEI. Jurnal Ilmu dan Riset Akuntansi, 3(3). Richard A. Brealy, Stewart C. Myers, Alan J. Marcus, (2008), Principle Of Corporate Finance, Global Edition, McGrawHill Inc.

Sitanggang, J.P, (2014), Manajemen Keuangan Perusahaan, Edisi Kedua, Mitra Wacana Media, Jakarta.

Sutrisno, (2013), Manajemen Keuangan, Edisi Pertama, Cetakan Kesembilan, Ekonisia, Yogyakarta.

Stephen A. Ros, Randolph W. Westerfield, Bradford D. Jordan, Josep Lim, Ruth Tan, (2011), Fundamentals of Corporate Finance, Asia Global Edition, Higher Education, Singapore. 